\title{
Lo Nobel que quita lo Noble
}

\author{
Francisco Pellicer ${ }^{1}$
}

El premio Nobel de Fisiología y Medicina del 2013, Randy Schekman, realizó declaraciones al periódico The Guardian en el sentido de que las revistas científicas más influyentes en el mundo como Nature, Cell y Science han malogrado el proceso de hacer ciencia y representan una tiranía que se debe romper. Declaró también que los resultados de sus investigaciones ya no serán mandados a publicar a estas revistas.

Ciertamente Schekman se refiere a la hegemonía que opera no solamente en términos de industria editorial científica, sino de la difusión o no de corrientes de pensamiento científico innovador y sobresaliente. Yo concibo su intervención como el grito de desacuerdo con todos estos procederes, que la mayoría de los científicos conocen o imaginan, y con los cuales, como él, no estamos de acuerdo, pero tendríamos que hacer un poco de análisis.

Es curioso que su voz se alce y se haga escuchar justo a raíz de obtener el premio Nobel, y me surge la primera pregunta: ¿si Schekman no hubiera publicado en esas revistas le hubieran dado ese premio? Para contestar esta primera aproximación revisamos a los laureados desde 1993 hasta el 2013; en 20 años lo han recibido 49 científicos. Todos ellos han publicado los resultados de sus investigaciones en revistas como Science, Nature, Cell, The Lancet, Jama, entre otras, antes de recibir el Nobel y en un rango tan amplio como una sola vez (en dos casos) hasta más de diez (tres casos). Lo curioso es que el número de las publicaciones se incrementa de forma sustancial después de recibir el Nobel y en más de ocho casos más de diez veces. Las contribuciones en térmi- nos de calidad científica de estas publicaciones posteriores, en su mayoría, son muy inferiores a la que dio origen a su postulación y a ser, finalmente, recipiendarios del Nobel. Ciertamente la mayoría de los avances más significativos se publican en las mencionadas revistas, pero no todos. De aquí me surge la segunda pregunta: ¿Los científicos que no han publicado sus hallazgos en este circuito hegemónico de revistas estaremos condenados a nunca obtener tal galardón? Ciertamente hacer ciencia, desde mi punto de vista, no está vinculado con el reconocimiento público o social, tiene otros motores; motores que tienen relación esencial con la búsqueda de la verdad, entendiéndose como verdad la resultante de comparar el modo de operar de la naturaleza con un constructo intelectual -teórico o empírico- inherente al observador, que se lleva a cabo mediante pasos y reglas que es lo que comúnmente denominamos como método científico. Es en la medida en la que esta comparación se acerca a la identidad, es decir nuestro constructo teórico de operación con la manera de operar de la naturaleza (en este caso naturaleza biológica relacionada con lo humano), que estamos más cerca del concepto de verdad. Hacer ciencia no es apegarse a las definiciones engendradas por lo que hoy conocemos como la teoría del conocimiento, sino un quehacer más emparentado con la intuición, la artesanía, el arte. En síntesis, es una postura filosófica en relación con el concepto de verdad y el de naturaleza, donde no tendrían cabida los factores de impacto de las revistas científicas, los claustros académicos invisibles, pero presentes y potentes $\mathrm{y}$ que acaban por desvirtuar tan Noble quehacer. 